\title{
ФОРМУВАННЯ ПЕДАГОГІЧНОЇ КУЛЬТУРИ В БАТЬКІВ, ЯКІ ВИХОВУЮТЬ ДИТИНУ 3 ІНВАЛІДНІСТЮ
}

\author{
Заверико Н. В. \\ кандидат педагогічних наук, професор, \\ професор кафедри сочіальної педагогіки \\ Запорізький національний університет \\ вул. Жуковського, 66, Запоріжжя, Украӥна \\ orcid.org/0000-0001-6175-0081 \\ nzaveryko@ukr.net
}

\author{
Ключові слова: \\ педагогічна культура, дитина \\ з інвалідністю, батьки, \\ щзо виховують дитину 3 \\ інвалідністю, просвітницька \\ робота, батьківська \\ компетентність.
}

У статті актуалізовано проблему формування педагогічної культури батьків, що виховують дитину з інвалідністю. Підкреслено значущість педагогічної взаємодії у цьому процесі. Проаналізовано сутність педагогічної культури батьків як компонента загальної культури людини, у якій знаходить віддзеркалення накопичений і безперервно збагачуваний попередніми поколіннями досвід виховання дітей у сім'ї; компоненти педагогічної культури батьків: теоретичний (наявність у батьків необхідного обсягу знань про розвиток, виховання, навчання дітей; про права дітей та обов'язки батьків; про пільги, умови навчання тощо); практичний (вміння взаємодіяти 3 дитиною, організовувати іï життя та діяльність, комунікативні та управлінські уміння; здійснення виховної діяльності, уміння прийняття рішень і критичного мислення; вміння взаємодіяти з різними виховними інститутами щодо отримання потрібних послуг та задоволення різних потреб дитини з вадами розвитку); емоційномотиваційний (характеризується прийняттям і позитивним ставленням до дитини, до ії вади; усвідомленням своєї ролі у вихованні та розвитку дитини 3 інвалідністю; формуванням батьківських якостей). Розкрито базові якості батьківської компетентності (толерантність, активність, асертивність). Представлено особливості формування педагогічної культури у батьків дитини 3 інвалідністю в освітньому закладі і в об'єднаних територіальних громадах. У загальноосвітньому середньому закладі просвітницьку роботу щодо формування педагогічної культури батьків, що виховують дитину з інвалідністю, здійснюють у формах батьківського всеобучу: батьківські тематичні збори, збори-практикуми; «години спілкування» 3 батьками, тренінги тощо. У територіальній громаді робота 3 батьками дітей з інвалідністю здійснюється фахівцем 3 соціальної роботи, соціальним педагогом відділу освіти і передбачає організацію соціально-педагогічної підтримки сім'ї 3 дитиною 3 інвалідністю, яка включає: соціально-педагогічний патронаж, психологопедагогічне консультування, організацію реабілітаційного процесу. 


\title{
FORMATION OF THE PEDAGOGICAL CULTURE OF PARENTS WHO GROW UP A CHILD WITH DISABILITY
}

\author{
Zaveryko N. V. \\ PhD in Pedagogy, Professor, \\ Professor at the Department of Social Pedagogy \\ Zaporizhzhia National University \\ Zhukovskoho str., 66, Zaporizhzhia, Ukraine \\ orcid.org/0000-0001-6175-0081 \\ nzaveryko@ukr.net
}

Key words:

pedagogical culture, disabled child, parents who bring up a child with disability, educational work.

\begin{abstract}
The article under consideration updates the problem of formatting the pedagogical culture of parents who grow up a child with disability. It emphasizes the importance of pedagogical interaction in this process. The essence of parental pedagogical culture as a part of general human culture and its components (theoretical, practical, emotional) have been analyzed. It differentiates gained by previous generations experience at children upbringing in a family. We give the reasons why parents are indifferent to pedagogical knowledge and characterize problems of families with disable children. Basic qualities of parental competence such as tolerance, activity, assertiveness are described. The author names main educational principles for adults that form the background of successful work with parents: the principle of subjectivity, the principle of entity between studying material and parental needs, entity of theory and practice, taking into consideration parents experience etc. The article reveals specific features of pedagogical culture formation at the educational institutes and in the community. In the general educational institutions the work with parents consists of such forms: teacher - parent meetings, practical meetings, situational cases, trainings etc. It is important that in the community the cross-disciplinary team works with families that grow up children with disabilities and it is focused on family socialpedagogical support to encourage parents' efforts in solving problems and tasks of habilitation and rehabilitation process, overcoming the initial depression and despair, focusing on child's individuality development and socialization as well as on treatment. We describe the formation of pedagogical culture of parents who grow up a child with disability at School of community parental competence: organization of patronage service work, parents education, the organization of rehabilitation process, psychological and pedagogical family support.
\end{abstract}

Постановка проблеми. Рівень педагогічної освіти батьків залежить від традицій у сім'ях, в яких вони виросли, від набутих знань, життєвого досвіду, здатності до саморозвитку. На сучасному етапі, у зв'язку з переходом до нового типу суспільства, утвердженням нових суспільних, етичних цінностей, а також з процесами глобалізації, педагогічна грамотність батьків нерідко відстає від реальної педагогічної ситуації, суспільних потреб, очікувань дитини.

Сім'я $\epsilon$ першим соціальним середовищем для дитини, в якому починається становлення особистості та від якого залежить, як саме відбуватимуться формування та розвиток особистості дитини. Протягом всього життєвого шляху особистості сім'я $\epsilon$ тим найближчим оточенням, яке визначає своєрідність іiї життєдіяльності.
Сім'я, що виховує дитину з інвалідністю, - це сім'я $з$ особливим статусом, особливості та проблеми якої визначаються не тільки особистісними якостями всіх іiі членів та характером взаємовідносин між ними, але й більшою занятістю вирішенням проблем дитини, закритістю сім'ї для зовнішнього світу, дефіцитом спілкування, відсутністю працевлаштування матері, але головне специфічним статусом у сім'ї дитини з інвалідністю, що зумовлено її хворобою.

Аналіз останніх досліджень i публікацій. Дослідженнями у сфері сімейної педагогіки, просвітницької роботи 3 батьками по формуванню педагогічної культури займаються як українські, так і зарубіжні науковці. Аспекти історичного досвіду сімейного виховання розглядали Ж.Ж. Руссо, I. Песталоцці, К. Ушинський, П. Лесгафт, П. Кап- 
терев, А. Макаренко, І. Бестужев-Лада, Г. Волков та інші. Проблеми психології сім'і, тактику сімейного виховання досліджували Т. Гаміна, О. Гончар, С. Ковальов, А. Співаковська, Г. Філіпова, О. Шаграєвата та інші. Шляхами зростання педагогічної культури батьків займалися І. Гребенніков, О. Звєрєва, В. Котрило, Є. Насєдкина, Р. Сережникова; питання просвітницької роботи 3 батьками та формування усвідомленого батьківства знайшли відображення у працях українських науковців Т. Алексеєнко, О. Безпалько, Л. Буніної, Т. Веретенко, І. Звєрєвої, Г. Лактіонової, І. Трубавіної та інших.

Різні аспекти порушеної проблеми висвітлювались у наукових працях А. Венгер, 3. Зайцевої, I. Іванової, А. Капської, М. Ніколаєва, С. Сварника, Е. Стребєлєвої, С. Тарасюк, які розглядали питання соціальної адаптації та соціалізації дітей 3 інвалідністю. Різні типи сімей, особливості їх функціонування, робота 3 родинами були предметом дослідження Л. Аксьонової, Т. Алексеенко, Є. Єкжанової, Л. Зіборової, О. Кононко, І. Трубавінової; технологічний аспект соціально-педагогічної роботи з сім'ями обгрунтований у наукових працях Н. Заверико, А. Капською, С. Харченко, особливості роботи 3 родинами, що виховують дитину з інвалідністю, висвітлювалися Н. Грабовенко, В. Жмиром, І. Івановою, Н. Писаренком, Т. Соловйовою, Т. Титаренком та інші.

3 впровадженням в Україні інклюзивної освіти на перший план виходять завдання, пов'язані 3 вихованням дорослих, з підготовкою їх до виконання батьківських функцій і ролей, до активної взаємодії з освітніми установами та їх фахівцями. Дослідники Е. Багаєва, І. Звєрєва, А. Москвіна, Н. Майструк зазначають, що специфіка сімейного виховання дітей з інвалідністю визначається своєрідністю їх психіки та необхідністю здійснення корекційних впливів на процес їх розвитку.

Попри велику кількість наукових досліджень 3 проблем формування педагогічної культури батьків, залишаються проблеми щодо організації цілеспрямованої роботи з батьками, що виховують дитину з інвалідністю, оскільки зміна освітньої парадигми з сегрегаційної на інклюзивну вимагає пошуку нових підходів до взаємодії з батьками.

Мета статті - розглянути основні підходи до формування педагогічної культури батьків, що виховують дитину з інвалідністю.

Виклад основного матеріалу. Під педагогічною культурою розуміється компонент загальної культури людини, у якій знаходить віддзеркалення накопичений і безперервно збагачуваний попередніми поколіннями досвід виховання дітей у сім'ї. Педагогічна культура батьків служить основою виховної діяльності батьків. Від рівня педагогічної культури батьків залежить успішність та результативність сімейного виховання дітей [1].

Сутність педагогічної культури полягає в особливому цілісному ставленні до дитинства як унікального, неповторного періоду людського життя й кожної дитини як самоцінності. Батьківська компетентність являє собою психолого-педагогічні знання та досвід, які можуть допомогти створити необхідні умови для розвитку гармонійної особистості дитини. Педагогічна культура батьків дозволяє істотно знизити елемент стихійності, властивий сімейному вихованню [2]. Компетентність батьків передбачає передусім чітке усвідомлення виховних цілей та засобів їх досягнення.

Слабо виявлений інтерес у здобутті додаткових знань про виховання дітей у багатьох батьків пояснюється, по-перше, недооцінкою самого сімейного виховання й переконанням в тому, що виховання та розвиток дитини є справою дитячих установ; по-друге, нерозвиненістю потреби у вихованні дітей, низькою активністю батьків, по-третє, вкрай вузьким розумінням виховних завдань, упевненістю в тому, що головною метою виховної діяльності $є$ виховання в дитини слухняності, звички дотримуватися батьківських порад та повчань.

Педагогічна культура батьків включає певні компоненти: теоретичний (наявність у батьків необхідного обсягу знань про розвиток, виховання, навчання дітей; про права дітей та обов' язки батьків; про цілі, засоби та методи виховання; засоби корекції та компенсації розвитку дітей $з$ інвалідністю, про пільги, умови навчання тощо); практичний (вміння взаємодіяти з дитиною, орга-

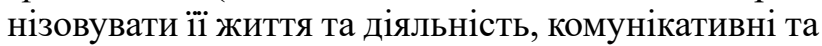
управлінські уміння; здійснення виховної діяльності, уміння прийняття рішень і критичного мислення; вміння взаємодіяти з різними виховними інститутами (державними і недержавними організаціями) щодо отримання потрібних послуг та задоволення пізнавальних, емоційних, комунікативних потреб дитини з вадами розвитку); емоційно-мотиваиійний (характеризується прийняттям і позитивним ставленням до дитини, до іï вади; усвідомленням своєї ролі у вихованні та розвитку дитини 3 інвалідністю; формуванням важливих батьківських якостей, потребою удосконалення батьківської компетентності тощо).

Сучасні науковці, що досліджують питання соціальної допомоги сім'ї з дитиною, важливу роль в ній відводять соціальному педагогу, одним iз професійних завдань якого $\epsilon$ - сприяти соціальній адаптації та реабілітації сім'ї 3 дитиною $з$ особливими потребами; підвищувати ситуаційно-рольову адаптованість, яка передбачає здатність членів сім'ї оволодіти новими поведінковими ролями в новій, досить несприятливій ситуації [3]. 
Для батьків, які виховують дитину з інвалідністю, соціальний педагог - це фахівець, який націлений на роботу з батьками для покращення умов життя та виховання дитини 3 інвалідністю, який здійснює соціально-педагогічну підтримку сім'ї, супроводжує iii, спонукає батьків до активної самодопомоги, особистісного розвитку та самореалізації у суспільстві.

Головна мета соціально-педагогічної діяльності в роботі з сім'єю дитини $з$ інвалідністю допомогти сім'ї справитися з важким завданням виховання дитини 3 різними порушеннями інтелектуального та фізичного розвитку, сприяти прийняттю батьками іiї вад, мобілізувати можливості сім'ї для вирішення завдань абілітації, корекціїі та реабілітації дитини.

Народження хворої дитини змінюе уклад i психологічний клімат у сім'ї. Усі члени родини і передусім мати перебувають у стані емоційного стресу. В такому стані багато батьків хочуть відмовитися від дитини. Щоб запобігти відмові від дитини і включити сім'ю в реабілітаційний процес, спеціаліст повинен мати реальні уявлення про перспективи дитини і ту роль, яку належить зіграти сім’ї в іiі розвитку і вихованні.

Аналіз реальної практики соціально-педагогічної роботи з родиною, яка виховує дитину з особливими потребами, дав можливість українській дослідниці Т. Соловйової визначити проблеми, 3 якими стикаються такі сім'ї: матеріальні труднощі, відсутність або недостатність інформації про можливості лікування, реабілітації дитини; іiі права та пільги, психологічні проблеми; низька мотивація батьків до роботи 3 представниками соціальних служб, феномен «соціального утримання», притаманний великій кількості батьків, соціальна ізольованість тощо [4]. Цей аналіз дає підстави для визначення питань щодо здійснення просвітницької роботи з батьками та підвищення їх педагогічної культури.

Формування педагогічної культури батьків - процес складний, інтегративний, динамічний, який передбачає чітку мету, структуру та системність. Метою формування педагогічної культури батьків, що виховують дитину з фізичними та /або інтелектуальними порушеннями, $€$ батьківська компетентність, яка включає усвідомлене ставлення до дитини, іiї потреб та здатність створити оптимальні умови для розвитку, виховання та навчання дитини з інвалідністю.

Обов'язковими складниками батьківської компетентності є базові якості особистості: толерантність, активність, асертивність [5]. Толерантність розглядається як терпимість батьків до почуттів, думок, поведінки дитини, як сприйняття та прийняття дитини такою, якою вона $\epsilon$. Ця якість проявляється тоді, коли батьки доз- воляють дитині робити власні помилки, робити вибір того, що вона бажає та вважає за найкраще для неї. Важливими складниками толерантності виступають педагогічна етика й такт, які в дійсності виражаються дуже різнобічно і $є$ наслідком глибини і розвиненості психолого-педагогічного мислення, вольової підготовки, загальної культури батьків. Етичні норми втілюються в індивідуальній діяльності батьків, у їх толерантності, що характеризується гнучкістю й обгрунтованістю застосування засобів, прийомів і форм взаємодії з дітьми, вдумливим, уважним підходом до потреб і інтересів дітей, неквапливістю й помірністю висновків у їх оцінці [5].

Під асертивністю розуміють певну особистісну якість, яку можна визначити як автономію, незалежність від зовнішніх оцінок, здатність самостійно регулювати власну поведінку [6]. Асертивність передбачає, що батьки знають, чого вони бажають і чого не бажають у конкретній ситуації, можуть чітко сформулювати - без страху, невпевненості, напруження, іронії, сарказму та інших форм нападу на протилежну сторону. Батьки, які ведуть себе асертивно, діють не на шкоду комусь, утверджують права інших людей, але при цьому не дозволяють обмежувати себе. Якщо інтереси стикнулися, такі батьки здатні домовитися i знайти компромісне рішення, що задовольнить обидві сторони. Асертивність як якість особистості визначає не тільки особливості поведінки, а й адекватний емоційний стан, що дуже важливо для батьків дітей з інвалідністю. Наявність цієї якості у батьків передбачає, що вони думають про себе, свою поведінку, оцінюють себе реалістично, а це добра база для набуття будь-якої навички, необхідної в контактах з власною дитиною та оточенням. Коли батьки знають свої права, вміють визначати свої потреби та відстоювати їх, тоді вони $є$ спроможними навчити цьому дітей та 3 повагою ставитися до їх прав, особливостей тощо [5].

Важливим складником батьківської компетентності $є$ активність як особистісна риса. Суспільна та особистісна активність батьків, що виховують дитину 3 порушеннями розвитку, розглядається як здатність батьків до спілкування $з$ дитиною, до творчості, вольових актів; це постійне прагнення батьків до самовдосконалення своєї особистості, підвищення рівня педагогічної культури, що сприяє створенню належних умов для реалізації інтересів та потреб дитини з інвалідністю, покращує і підвищує рівень виконання батьками своїх обов'язків по відношенню до дитини. Суспільна активність дуже важлива для таких родин, тому що соціальна ізоляція сім'ї 3 дитиною 3 інвалідністю негативно впливає на соціалізацію самої дитини та ії̈ оточення. Крім того, така активність проявляється у діяльнісному ставленні батьків 
до життя суспільства, в якому вони виступають як ініціативні носії та провідники норм, принципів, цінностей демократичного суспільства. Можливостей для прояву суспільної активності сьогодні дуже багато, оскільки протягом останніх 20-ти років 3'явилась велика кількість громадських організацій батьків дітей 3 інвалідністю, таких як: Національна Асамблея людей з інвалідністю України; Громадська організація «Спілка батьків дітей-інвалідів» (м. Сміла); Громадська організація «Асоціація батьків дітей 3 інвалідністю та особливими потребами» (м. Луцьк); Громадська організація для дітей 3 особливими потребами та їх батьків; Благодійна організація «Право на життя дітей 3 обмеженими можливостями» (м. Запоріжжя); Громадська організація «Особливий дотик» (м. Кривий ріг); БО «Криворізька міська організація допомоги дітям та людям з синдромом Дауна “Сонячні діти Криворіжжя”». (м. Кривий ріг); Громадське об’єднання батьків дітей-аутистів «Рука в Руці» та інші.

Педагогічна культура батьків дітей з інвалідністю формується завдяки організації просвітницької роботи з такими сім'ями, яка має враховувати принципи навчання дорослих: принциип суб'єкmності (або активності): досягнення суб'єктності батьків у навчанні; взаємозв'язок активності та усвідомлення; принции взаємозв 'язку змісту навчання із пізнавальними потребами батьків; приничи демократичних взаємовідносин: навчання на засадах партнерської взаємодії; створення доброзичливої атмосфери навчання; принции ичінності пізнавальної діяльності: значимість навчання; принцип взаємозв 'язку теорії з практикою: корисність навчання; принциип відповідності підбору змісту та методів навчання: використання різноманітних методів навчання; принцип урахування індивідуальних особливостей та особистісного досвіду батьків: сприйняття життєвого досвіду батьків та повага до нього [7].

У сучасних умовах роботу щодо формування педагогічної культури батьків, що виховують дитину 3 інвалідністю, можна здійснювати як в освітньому закладі, так і у територіальних громадах. Зазвичай у навчальному закладі соціальний педагог та педагогічні працівники здійснюють зв'язок з батьками у таких формах батьківського всеобучу: батьківські тематичні збори, на яких розглядаються питання морального виховання дітей; збори-практикуми; батьківські збори у формі «годин спілкування», які вможливлюють коригування взаємин батьків і дітей у сім і; проведення батьківських зборів у формі гри; тренінги тощо [8].

Робота з батьками, що виховують дитину з інвалідністю, у територіальній громаді здійснюється фахівцем з соціальної роботи, соціальним педагогом відділу освіти. Вона передбачає організацію соціально-педагогічної підтримки сім’ї 3 дитиною 3 інвалідністю. Головна мета такої роботи допомогти сім’ї справитись 3 важким завданням виховання дитини 3 порушеннями розвитку, впливати на сім'ю $з$ тим, щоб мобілізувати їі можливості для вирішення завдань абілітаційного та реабілітаційного процесів. Організація допомоги батькам дитини 3 інвалідністю в територіальній громаді цінна тим, що соціальний педагога починає працювати 3 перших днів повернення породілля додому. Завдання соціального педагога допомогти батькам подолати первинну реакцію пригніченості і розгубленості, а надалі зайняти активну позицію в реабілітації дитини, зосередивши зусилля батьків не лише на лікуванні, а й на розвитку іiі особистості, на пошуку адекватних способів соціалізації і досягнення оптимального рівня адаптації у соціумі.

Формування педагогічної культури батьків, що виховують дитину 3 порушеннями розвитку, може бути здійснено у «Школі батьківської компетентності», завдання якої - підтримка та розвиток традицій родинного виховання, спрямованих на зміцнення сім’ї, обговорення концептуальних засад сімейного виховання, народної педагогіки, проблем виховання дітей з особливими освітніми потребами в родині; надання допомоги батькам, які не справляються 3 вихованням неповносправних дітей (допомога перейти від позиції вболівання до творчого пошуку реалізації можливостей дитини 3 особливими потребами; корекція внутрішнього стану батьків, переорієнтація батьків 3 позиції «очікування дива» на позицію діяльності та допомогу дитині у іiі розвитку, навчанні, реалізації їі здібностей тощо.

Програма Школи батьківської компетентності включає кілька блоків:

1. Організація патронатної служби. Оскільки медична служба здійснює лікування дитини, фахівець $з$ соціальної роботи в громаді здійснює соціально-педагогічний патронаж, який забезпечується на основі контракту, що заключає сім'я 3 соціальним педагогом. Патронаж допомагає сім’ї подолати кризу, впоратися 3 труднощами виховання дитини 3 порушеннями розвитку, він також включає посередницьку допомогу - взаємодію 3 медичними установами, встановлення контактів 3 родичами, сім'ями, що мають подібні проблеми, 3 громадськими організаціями, що здатні надати допомогу; $з$ державними органами тощо. Патронаж передбачає обов'язкове відвідування сім'ї на дому, встановлення довірливих стосунків з батьками, налагодження ділового та доброзичливого спілкування;

2. Просвіта батьків. Цей блок стає дуже важливим компонентом «Школи батьківської компетентності». Він передбачає інформування щодо 
нормативних документів, прав та обов'язків батьків, пільг, умов отримання матеріальної допомоги; консультування 3 питань виховання дитини, організації їі життєвого простору, умов для розвитку; організація заходів, спрямованих на зміцнення родинних стосунків, тощо. Форми такої роботи можуть бути як індивідуальні (консультації, бесіди), так і групові (тренінги, ігри, обговорення ситуацій, дискусії 3 питань виховання, обмін досвідом, зустрічі $з$ лікарями, юристами, психологами, представниками державних установ, громадських організацій тощо).

3. Організація реабілітаційного процесу 3 участю батьків передбачає знайомство 3 діагнозом, його наслідками, потенційними можливостями дитини, перспективами лікування тощо. Важливе місце в цьому напряму відводиться мультидисциплінарній команді фахівців, у яку входитимуть соціальний педагог, психолог, лікар, логопед, невропатом, реабілітолог та інші. Батькам надаються практичні поради по догляду за дитиною, рекомендації щодо вирішення повсякденних проблем, пов'язаних 3 вихованням особливої дитини та протіканням iї хвороби.

4. Психолого-педагогічна підтримка сім’ї 3 дитиною включає корекцію емоційного стану та поведінки батьків, оскільки батьки не завжди проінформовані про причини відхилень, методи саморегуляції, про особливості взаємодії з дитиною. Виокремлюють такі напрями: гармонізація сімейних стосунків; корекція психічного стану матері; корекція дитячо-батьківських стосунків; допомога в адекватній оцінці можливостей дитини (як фізичних, так і психологічних); навчання матері спеціальним корекційним і методичним прийомам для проведення занять 3 дитиною в домашніх умовах; навчання матері спеціальним виховним прийомам, необхідним для виховання дитини.

Висновки та перспективи дослідження. На основі аналізу наукової літератури та сучасної практики можна зробити висновок про те, що формування педагогічної культури батьків, що виховують дитину з інвалідністю, базується на глибокому знанні специфіки такої категорії. Проблеми, 3 якими стикаються сім’ї, що виховують дітей 3 порушеннями фізичного та інтелектуального розвитку, зумовлюють необхідність цілеспрямованої роботи 3 такими сім'ями, з урахуванням діагнозу дитини та їі віку.

3 огляду на вищезазначене під час організації батьківського всеобучу слід враховувати потреби батьків, їх емоційний стан, спроможність допомогти своїй дитині. Розуміючи те, що сім'я 3 дитиною з інвалідністю може потрапити у складні життєві обставини, формування педагогічної культури та батьківської компетентності повинно сприяти становленню батьків як активних суб'єктів свого життя, здатних самостійно запобігати i вирішувати можливі проблеми своєї дитини.

\section{Література}

1. Гаміна Т., Гончар О. Педагогіка сімейного виховання : навчальний посібник. Луганськ : Альма-матер, 2012. $523 \mathrm{c}$.

2. Титаренко В. Я. Семья и формирование личности. Москва : Мысль, 1987. 352 с.

3. Майструк Н.О., Лучаківська, А.Р. Проблеми сімей, що виховують дітей з особливими фізичними можливостями в сучасній Україні, в контексті соціальної роботи. Вісник НТУУ «КПІ». Політологія. Соиіологія. Право. 2010. № 3. С. 85-89.

4. Соловйова Т.Г. Соціально-педагогічні засади роботи з батьками дітей з особливими потребами : автореф. ... канд. пед. наук : 13.00.05 / Інститут проблем виховання АПН України. Київ, 2009. 22 с.

5. Шевченко Н.Ю. Соціально-педагогічні засади формування усвідомленого ставлення батьків до прав дитини : дис . ... канд. пед. наук : 13.00 .05 / Луган. нац. пед. ун-т ім. Т. Шевченка. Луганськ, 2006. $228 \mathrm{c}$.

6. Большой психологический словарь : словарь / под ред. Б. Г. Мещерякова, В. П. Зинченко. 3-е изд., перераб. и доп. Санкт-Петербург : Прайм-Еврознак, 2006. 672 с.

7. Заверико Н.В., Шевченко Н.Ю. Просвіта батьків як ціннісна парадигма освіти в контексті євроінтеграції. Педагогічні шляхи реалізаиії загальноєвропейських иінностей у системі освіти Украӥни. Харків : Стилыздат, 2005. С. 110-114.

8. Матвієнко О.В. Формування педагогічної культури батьків у процесі педагогічної взаємодії сім'ї та школи. Теоретико-методичні проблеми виховання дітей та учнівської молоді. 2015. Вип. 19 (2). C. 6-15.

\section{References}

1. Gamina T., Gonchar O. (2012) Pedagogika simejnogo vihovannya [Pedagogy of family education]. Lugansk : Alma Mater [in Ukrainian].

2. Titarenko V. Ya. (1987) Semya i formirovanie lichnosti [Family and personality formation]. Moscow : Mys1 [in Russian]. 
3. Majstruk N.O., Luchakivska, A.R. (2010) Problemi simej, sho vihovuyut ditej z osoblivimi fizichnimi mozhlivostyami v suchasnij Ukrayini v konteksti socialnoyi roboti [The problems of families, which raising children with disabilities in modern Ukraine in the context of social work] Bulletin of NTUU "KPI". Politology. Sociology. Right. Vol. 3. P. 85-89.

4. Solovjova T.G. (2009) Socialno-pedagogichni zasadi roboti z batkami ditej z osoblivimi potrebami [Socio-pedagogical basis of work with parents of children with special needs]. Extended abstract of candidate's thesis. Kyiv : Institute of Education Problems of the Academy of Pedagogical Sciences of Ukraine [in Ukrainian].

5. Shevchenko N.Yu. (2006) Socialno-pedagogichni zasadi formuvannya usvidomlenogo stavlennya batkiv do prav ditini [The social-pedagogical means of forming of parents conscious attitude to children rights]. Extended abstract of candidate's thesis. Lugansk: Lugansk Taras Shevchenko National Pedagogical University [in Ukrainian].

6. Mesheryakova B.G., \& Zinchenko V.P. (eds.). (2006) Bolshoj psihologicheskij slovar [Big psychological dictionary]. Sankt-Peterburg : Prajm-Evroznak [in Russian].

7. Zaveriko N.V., Shevchenko N.Yu. (2005) Prosvita batkiv yak cinnisna paradigma osviti v konteksti yevrointegraciyi [Parental education as a paradigm of values education in the context of European integration] Pedagogical ways to implement European values in the education system of Ukraine. Kharkiv : StyleIzdat, P. $110-114$.

8. Matviyenko O.V. (2015) Formuvannya pedagogichnoyi kulturi batkiv u procesi pedagogichnoyi vzayemodiyi sim'yi ta shkoli [Parents' Pedagogical Culture Shaping in the Process of Family and School Pedagogical Interaction] Theoretical and Methodical Problems of Children and Youth Education. Vol. 19 (2). P. 6-15. 